\title{
“Parabéns pra você": reflexões na quarentena sobre a transição de uma bebê para a creche
}

\author{
FERNANDA MÜLLER \\ UNIVERSIDADE DE BRASÍLIA (UNB), BRASÍLIA/DF, BRASIL \\ HTTPS://ORCID.ORG/OOOO0-0002-I788-8662
}

Há 20 anos, Alma Gottlieb (2000) perguntava: "Para onde foram todos os bebês?”'. A pergunta, retórica e metafórica, indicava a indiferença ou o pequeno espaço ocupado por esses sujeitos na pesquisa antropológica, que não raramente são considerados em falta ou simplesmente não sujeitos. Gottlieb argumentou que os bebês são geralmente desassociados daquilo que para a Antropologia é fundamental, isto é, a cultura. Isso porque a noção de cultura está conectada à linguagem e, mais ainda, à oralidade. Diante da temporária ausência de fala, eis um primeiro suposto impasse para considerá-los sujeitos próprios de pesquisa.

Todavia, ao apresentar as razões que fundamentariam a quase ausência de bebês na disciplina, Gottlieb sugere, simultaneamente, a identificação de um problema e, indiretamente, a sua solução. Argumenta que poucos de nós seríamos capazes de acionar memórias do tempo em que fomos bebês; tampouco seria possível a todos/as os/as antropólogos/as empreenderem um olhar sobre eles quando se tornam mães ou pais. Um outsider, pela distância, talvez tivesse mais vantagem. Todavia assumo aqui a possibilidade de aproximação a esse "outro" por meio de uma saída que não a maternidade nem o status de completa outsider. Está na base de nossa formação certos dispositivos que nos tornam mais sensíveis a "ouvir, olhar e escrever" (Cardoso de Oliveira 1996), exercício que foi aqui conectado à emergência de uma nova identidade, nesse caso, a de tia e madrinha de primeira viagem.

Um tratamento sistemático de relações e vínculos construídos e revisados em família, a partir do nascimento de uma criança, poderia ser uma saída para a Antropologia no enfrentamento a essa já

1 “Where have all the babies gone?", no original. Muitas outras perguntas compuseram títulos de importantes trabalhos antropológicos sobre crianças. Cito somente algumas, que mereceriam, em outro trabalho, uma atualização de acordo com outros contextos e culturas: "Pode haver uma antropologia das crianças?” (No original, "Can there be an Anthropology of Children?”, Hardman 1973); “Os bebês têm religião?” (“Do infants have religion?”, Gottlieb 1998); “Por que os antropólogos não gostam de crianças?” (“Why don't anthropologists like children?”, Hirschfeld 2002); “Os bebês têm cultura?” (“Do babies have culture?”, Toren 2004). 
constatada lacuna na literatura. A dupla experiência pessoal e profissional poderia retirar de uma vez por todas as dúvidas que ainda recaem sobre os bebês - "mais próximos dos animais ou dos não-humanos"? (Pires e Saraiva 2019:10). Obviamente, a pesquisa sobre e com bebês nos impõe desafios de diversas ordens. Vou ater-me a três deles, ainda, de forma provisória e/ou ensaística: 1) sobre quem são os bebês; 2) sobre método; e 3) sobre ética.

Para Mauss, a noção de pessoa, o "eu”, não é natural nem inata, embora a tendência seja a de naturalizar e tomar como automáticas ações que, de fato, foram apreendidas ao longo da vida e ajustadas de acordo com o esperado em cada cultura e cada sociedade (Mauss 1973[1938]). Bebês são pessoas e, mais do que isso: "A produção social da criança não é apenas a criação de mais uma pessoa, mas a redefinição das relações entre os que estão diretamente envolvidos" (Machado 2013: 100). Se Machado (2013:103) elabora a relação entre pais e entre pais e crianças como um "híbrido", "um tipo de amálgama de diferentes ordens de fatos", aqui eu incorporaria ainda outros membros da família diretamente envolvidos na criação e educação de um bebê.

A respeito dos aspectos metodológicos, Pires e Saraiva (2019: 10) formulam uma pergunta, ao encontro desse estado ainda incipiente dos estudos antropológicos sobre e com bebês no Brasil: enquanto antropólogas sociais, estaríamos "preparadas metodologicamente para incluir os bebês nas pesquisas"? Além disso, questionam se a observação participante, reconhecida como o método tradicional de nosso ofício, seria o mais adequado para conduzir investigações sobre e com bebês. Tal como sugere Gottlieb (2000; 2004), nesse caso, os bebês poderiam ser considerados como textos a serem lidos (Geertz 1989) por nós com a ajuda de seus/suas cuidadores/as. Operaríamos em uma hermenêutica para compreender esse "outro" por meio de um/a tradutor/a, que poderia dar sentido a outras linguagens acionadas, como é o caso dos gestos ${ }^{2}$.

Com relação aos aspectos éticos, Pires e Saraiva (2019: 11) questionam se o choro dos bebês poderia ser considerado uma resposta negativa ao consentimento. A pergunta é altamente instigante. Se o choro, assim como muitas outras manifestações de bebês, for entendido como linguagem, porque comunica, só caberia como resposta "cada caso é um caso". O choro, também um texto, precisa ser lido e mais, de acordo com o contexto e a relação. Em família, pode ter sentidos diversos (que as mães bem traduzem como "manha", "fome" ou "sono"), mas em contextos coletivos, como é o caso da creche ${ }^{3}$, pode estar associado a engajamento, interação, solidariedade ou até mesmo disputa entre pares. Uma nova pergunta decorre daí: como estudar possibilidades comunicativas de bebês sem nos aproximar-

2 Ao encontro da obra de Erving Goffman, Charles Goodwin (2007: 198) argumenta: "em vez de ser algo que pode ser estudado isoladamente como um sistema limpo e autocontido, o gesto é um fenômeno intrinsecamente parasitário, algo que obtém seu significado e organização da maneira como está fluidamente ligado a outras práticas de criação de significado e sistemas de signos que estão constituindo os eventos do momento" (no original: "rather than being something that can be studied in isolation as a neat, self contained system, gesture is an intrinsically parasitic phenomenon, something that gets its meaning and organization from the way in which it is fluidly linked to the other meaning making practices and sign systems that are constituting the events of the moment").

$3 \mathrm{O}$ presente trabalho não toma a creche como um campo de pesquisa. Todavia há de se reconhecer, sem esgotar aqui uma revisão bibliográfica acerca do tema, trabalhos dos campos da Psicologia e da Educação que apresentaram estados da arte sobre as mais diversas relações de bebês no contexto da creche: Rocha e Gonçalves (2015); Silva e Müller (2015); Salutto e Nascimento (2019); Silva e Neves (2020). Igualmente, trabalhos que documentaram processos de interação de bebês: Amorim, Vitoria e Rossetti-Ferreira (2000); Vasconcelos et al. (2003); Coutinho (2010). 
mos do choro, como linguagem? Cada caso é um caso, porque, nas mais diversas experiências, o choro também pode não ser uma manifestação de sofrimento, nem estar direcionado à pesquisadora.

Dependemos, portanto, de intermediário/as, tanto na produção do dado etnográfico, quanto, no caso do presente artigo, na tomada de decisões que envolveram a exposição de pessoas, nomes, imagens e ideias. As pessoas envolvidas foram convidadas a ler uma versão preliminar do artigo ${ }^{4}$, a analisar e a emitir opiniões. Revisaram decisões anteriores e optaram, na versão final, pela apresentação de seus nomes, ao invés de pseudônimos e fotografias originais, com sensíveis edições. Essas decisões decorreram de um processo de negociação proposto por mim, que foi aceito e seguido de reflexão e disponibilidade de todos/as os/as envolvidos/as 5 .

Proponho dois deslocamentos para o presente artigo. O primeiro, da metáfora para uma realidade, quando exploro os sentidos que o "Parabéns pra você" ganhou na preparação de uma festa de aniversário e na transição de uma bebê para a creche. O segundo refere-se à já identificada lacuna de estudos sobre e com bebês na Antropologia para um esforço de tornar dados tão subjetivos, ou melhor, produzidos a partir de um intenso encontro intersubjetivo, em dados objetivos, traduzidos. A quarentena escancarou uma rede de solidariedade que já operava discretamente em uma família e que superou qualquer barreira física. Notícias passaram a chegar a todo o momento por meio de ligações telefônicas e envio de fotografias, vídeos e o mais interessante: no centro desses discursos duas bebês eram posicionadas e reposicionavam, sobretudo, mulheres em seus afetos e reciprocidades. Esse cenário não teve a ver com um limite particular, mas imposto a milhares de famílias: considerados como grupo de risco já no início da quarenta, os avós recolheram-se e foram protegidos das crianças, que, ao contrário, foram associadas ao grupo que apresentava riscos de transmissão do coronavírus aos demais.

Por meses, avós não puderam conviver com os/as netos/as tal como antes ocorria. As mães passaram a acumular tarefas decorrentes de suas agendas profissionais e do reencontro com as crianças em casa em tempo integral, já que as atividades de creches, pré-escolas e escolas foram suspensas. Parece que parte da solução para lidar com a saudade e o distanciamento entre avós e crianças foi a produção intensiva de vídeos, fotografias e até áudios, para informar o que ocorria do lado de lá e que não podia ser visto ao vivo.

Esse material, no meu caso, transformou-se em dado etnográfico. A própria reclusão incitou o desejo por uma análise a respeito do que estava se passando na família, à distância, mas também sobre o que já havia se passado. Mais do que isso, a Antropologia já acumulou trabalhos que exploraram fenômenos sociais a partir das experiências em família dos/as próprios/as pesquisadores/as (Motta-Maués 2004; Duarte e Gomes 2008; Machado 2013). Foi na quarentena que a reflexão acerca de eventos que

\footnotetext{
4 Ou seja, o próprio artigo entrou em circulação. E isso gerou as mais diversas respostas, dentre elas, a expressão de emoções de felicidade por algumas, que entendiam se tratar de um registro histórico, que, para além da socialização de uma bebê, contava sobre a vida de uma família. Outras ficaram felizes com a possibilidade de publicação do artigo. Assim como registrado por Duarte e Gomes (2008:38), ocorreu uma "leitura crítica e discussão dos textos produzidos e dos procedimentos empregados", e, nesse caso, me foram enviados comentários gerais, mas também pontuais, que variaram de correções ortogramaticais a pedido de esclarecimento e aprofundamento de ideias, algumas delas coincidentes com as solicitações dos pareceres de avaliação.

5 Agradeço ao Leo, à Marlene, ao Luiz, à Renata, ao Rodrigo, à Eni e à Élen, que, em meio a tantos afazeres decorrentes da quarentena, ainda assim se disponibilizaram a ler e a comentar uma versão anterior do trabalho. Ainda agradeço à Professora Tânia Mara Campos de Almeida, que foi quem motivou as reflexôes que deram origem à escrita do trabalho. Sou ainda grata aos comentários do Professor Juarez J. Tuchinski dos Anjos.
} 
ora me foram narrados, ora por mim diretamente observados e registrados passaram a ganhar um sentido ímpar. Ampliei a escuta a essas mulheres para pensar sistematicamente a respeito da chegada de uma bebê a esse mundo, onde nós, os adultos, chegamos com um pouco mais de antecedência.

$\mathrm{O}$ artigo tratará de diferentes encontros e relações que apoiam a reflexão acerca da socialização nos primeiros anos de vida e, para isso, buscará um fio condutor, ou seja, os rituais de transição de Mariana nesse mundo mediado por outros, que, junto com ela, experimentam o ineditismo de novas identidades, seja de bisavó, avós, mãe, pai, tios, irmão, primos, padrinho e madrinha. Portanto aqui não interessa tanto para onde os bebês foram, mas como circulam no mundo (Motta-Maués 2004) e transformam relações ${ }^{6}$.

\section{O encontro de duas bebês e a renovação de uma família}

Há quase três anos, o nascimento de Mariana, filha de minha única irmã que é mais jovem, apresentou-me um questionamento acerca da compreensão de bebês como sujeitos passivos ou secundários, de forma particular, em minha família, e, em geral, na sociedade. A bebê nasceu em janeiro de 2018, pouco mais de dois meses após o nascimento de Verônica, neta de Eni, irmã de minha mãe (vide o diagrama genealógico apresentado mais à frente).

Junto com elas, as bebês trouxeram a esperança e a renovação de uma família de classe média em que a formação acadêmica e a colocação profissional foram prioridades para a terceira geração. Mais do que isso, trouxeram conforto àqueles membros que não (ou ainda não) escolheram a maternidade ou a paternidade para si, mas que delas participam radicalmente - no sentido simbólico e gramatical: Fernanda e Leo, no caso de Mariana, e Emili e Eder, no caso de Verônica, tornaram-se madrinhas e padrinhos.

No meu caso, que há mais de uma década vivo a mais de dois mil quilômetros distante de meus pais, a partir do nascimento de Mariana, passei a visitá-los, em média, a cada dois meses, o que foi interrompido desde março de 2020 devido à pandemia. Como avós iniciantes, ambos se viram envolvidos e corresponsáveis pelo cuidado da neta, o que foi facilitado pelo fato de minha irmã e seu marido viverem na mesma cidade, a aproximadamente cinco quilômetros de distância.

O processo de socialização de Mariana começou a se delinear como central, o que passei a observar por meio dos diferentes rituais de transição que envolveram, principalmente, a família da linha materna e a creche nesse curto período. Esses processos não dizem somente respeito à bebê, mas todos os envolvidos na educação de crianças passam por transições significativas e também são socializados. Mais do que um processo de socialização unilateral, seriam leituras e aprendizagens mútuas que uns fazem dos outros, já que os contextos são sempre "negociados" (Ingold 2007:113).

Mariana, nesse caso, é ego, o indivíduo de referência, a partir de quem as relações de parentesco são descritas (Augé 1975). O simples diagrama que segue coloca outras relações em evidência, melhor, processos de socialização referentes aos adultos: Nelly tornou-se bisavó das duas bebês em um intervalo

6 Já argumentava Mauss: "Todo problema sociológico - mesmo aqueles que dizem respeito à criança - tem múltiplas relações com todos os outros problemas sociológicos ou mesmo antropológicos” (2010[1937]: 241). 
de pouco mais de dois meses; Marlene e Eni, irmãs, tornaram-se avós; Renata e Élen, primas, tornaram-se mães; os demais primos tornam-se tios (e padrinhos de suas respectivas sobrinhas). Mariana e Verônica são as novas integrantes da família, que colocam em circulação informações, emoções e sentimentos entre os adultos.

\section{Imagem 1: Diagrama genealógico.}

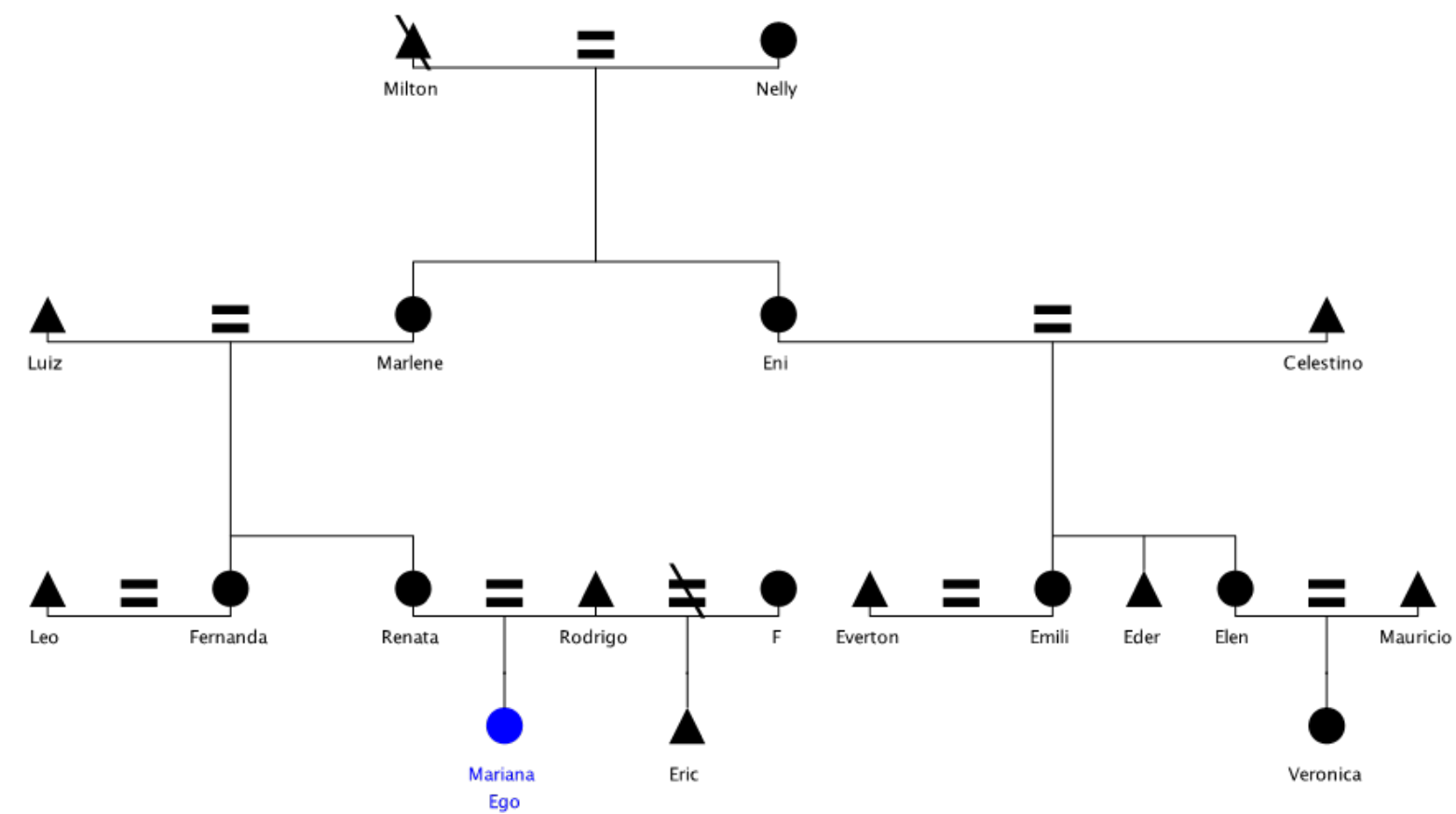

Mariana e Verônica vivem com seus pais e mães, porém ambas não têm contato constante, porque, embora localizadas na região Sul do país, as cidades onde residem se localizam a aproximadamente mil quilômetros de distância. Portanto as primas tiveram contato em períodos em que Verônica visitou os seus avós maternos, os quais moram na mesma cidade que os pais de Mariana. Contudo vínculos afetivo-emocionais fortes e pertencimento a uma rede de sociabilidade independem de proximidade física.

Em novembro de 2018, pai, mãe e Verônica viajaram à cidade natal dos avós maternos para a comemoração do primeiro aniversário da bebê, que ocorreu em uma casa de festas e contou com a presença de parentes e amigos. Mariana, seus pais, avós e bisavó encontravam-se entre os/as convidados/ as. Ao adentrar o salão, no colo do pai, Mariana encontrava-se com seu dedo indicador direito em riste. Assim seguiu no trajeto, sem baixar a mão nem o dedo, até encontrar-se com a prima aniversariante. Tal gesto não passou despercebido e a fotografia a seguir capturou o instante do encontro. 
Imagem 2: O encontro de Mariana e Verônica.

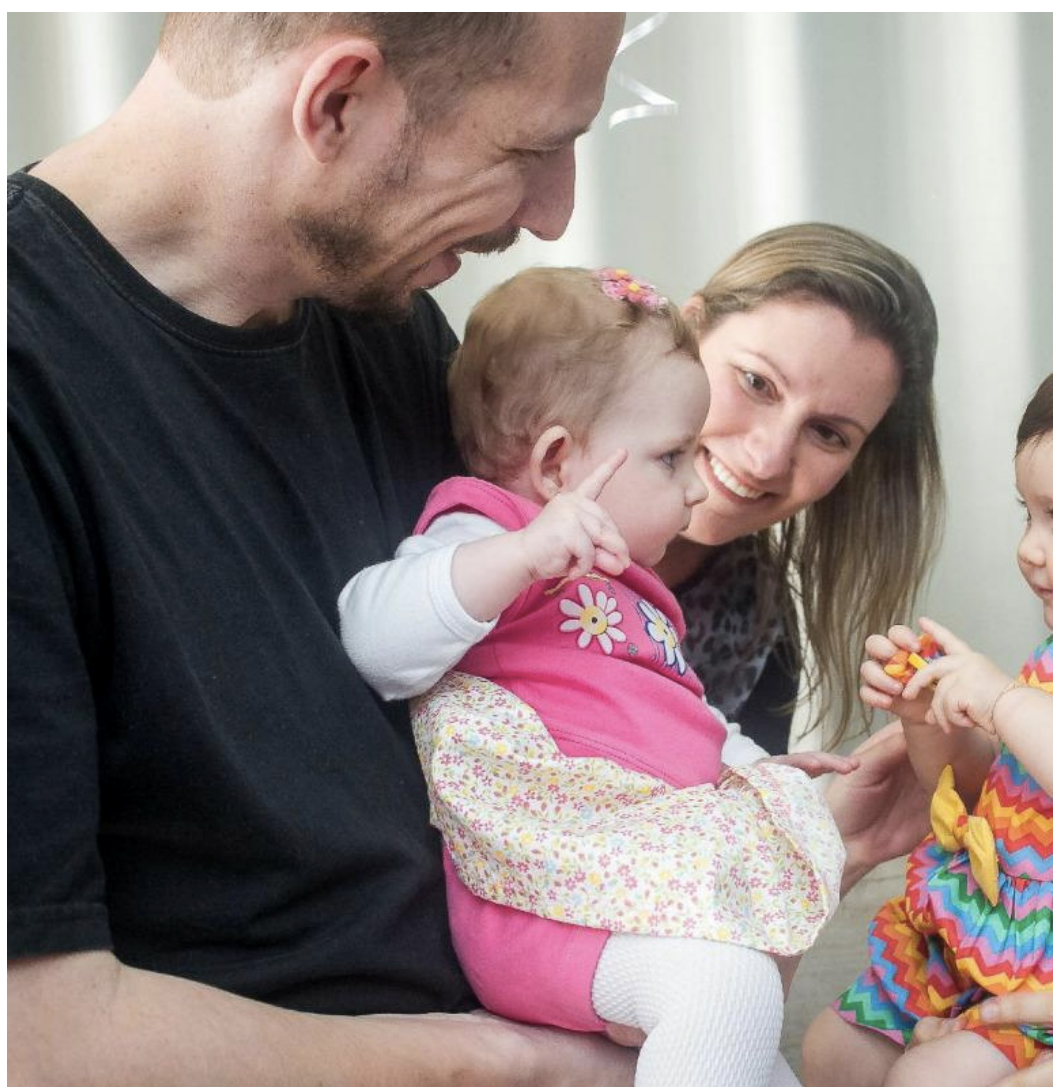

Fonte: Fotografia (com sensível edição) realizada por Anahi Smolski em novembro de 2018.

Talvez pela surpresa que causou, Rodrigo, Renata e a própria aniversariante, Verônica, fixaram o olhar em Mariana. Ao gesto foram dados vários sentidos, e justamente, pelas mulheres. Eni interpretou o gesto como se Mariana estivesse mencionando o primeiro ano de sua neta. Mais do que isso, foi compreendido como uma homenagem à Verônica. Avó e mãe de Mariana, Marlene e Renata, concordaram com essa interpretação e a reiteraram todas as vezes que a fotografia circulava. Era como se a bebê tivesse consciência de que a celebração completava um ciclo, o primeiro ano. Élen, mãe de Verônica, mencionou a emoção do encontro, na medida em que pôde observar a chegada de Mariana e a manutenção do gesto em direção a si e a sua bebê. E todos esses discursos, aliados à própria imagem, mostram uma composição em que os adultos estão apoiando, tal como andaimes, as bebês e o encontro. As bebês estavam, definitivamente, no centro, não só da imagem, mas das vidas dos adultos dessa família. Assim, os gestos - o dedo em riste e a troca de olhar fixo entre ambas - ganharam o significado, novamente entre as mulheres, do reconhecimento uma da outra.

O dedo em riste, no entanto, não foi só acionado no momento da chegada à festa. Em outra fotografia, junto ao bolo 7 , Mariana, que se encontrava no colo de Rodrigo (seu pai), enquanto Verônica

\footnotetext{
7 Régine Sirota etnografou aniversários de crianças por um período prolongado. Acerca do papel central do bolo no ritual, escreve: "Cercado de regras precisas, que expressam a excepcionalidade do dia, coloca no centro da cerimônia aquele que se festeja e que vai, rodeado do seu círculo social - família(s), amigos, escola -, assoprar as velas simbolizando a passagem para outra idade. Também testemunha o crescente lugar da criança em nossas sociedades" (no original: "Entouré de règles précises, qui disent l'exceptionnalité du jour, il met au centre de la cérémonie celui qui est célèbré et qui va, entouré de son cercle social - famille(s), amis, école -, souffle les bougies symbolisant le passage à un autre âge. Il témoigne aussi de la place grandissante de l'enfant dans nos sociétés") (Sirota 2014:28).
} 
estava no colo de Renata (sua mãe), mantinha o gesto. A composição dessa outra fotografia é igualmente relevante. Primeiro pela presença de dois duplos: dois adultos, em pé, seguravam duas bebês em seus colos. Atrás, um cenário de fundo de mar: uma cortina com dois peixes (um amarelo com listras em dois tons de azul e o outro roxo) e uma estrela-do-mar branca, todos em tecido. À frente, o falso bolo, em três andares, que correspondem a três tons de azul, com elementos do fundo do mar na cor branca. De um lado do bolo, um cavalo-marinho nas cores branca e azul e, do outro, uma baleia cachalote e um peixe azulado com listras vermelhas. E o mais interessante: os animais encontram-se em versão beb $\hat{e}^{8}$.

Após a festa de aniversário de Verônica, Rodrigo e Renata começaram a organizar os preparativos do aniversário de Mariana, que aconteceria em janeiro de 2019. Foi decidido que a celebração também ocorreria em uma casa de festas e preveria o convite a aproximadamente 80 pessoas ${ }^{9}$. Tudo passou a ser pensado em função do conforto e da familiaridade da criança, começando pelo tema da festa - "Mundo Bita"10.

\section{Imagem 3: O tema da festa: “O Mundo de Bita”.}

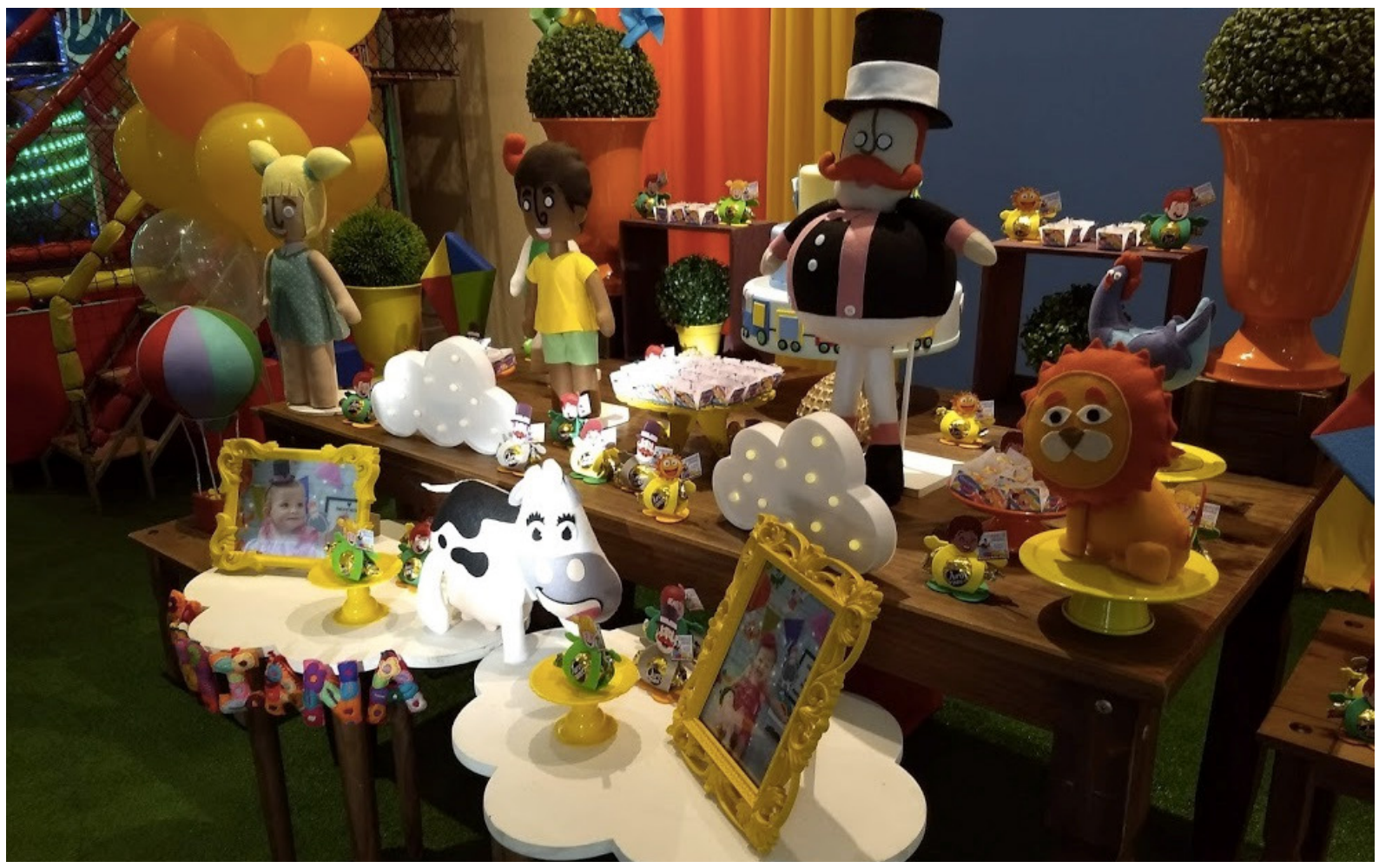

Fonte: Fotografia realizada por Leo em janeiro de 2019.

8 As festas de aniversário, sobretudo de um ano de bebês, poderiam ser eventos interessantes para a pesquisa antropológica, incluindo aquilo que Machado (2006) elaborou como "nenezidade". O autor associa a "nenezidade" a um totemismo do mundo dos bebês, em que tudo deve ser purificado e esterilizado de tabus sexuais, alimentares etc. Até bichos peçonhentos e insetos se tornam bebês, já que "tudo é sacrificado à representação de um mundo 'aos pés' do bebê” (Machado 2006:393).

9 Verônica e seus pais não puderam participar do aniversário devido a uma viagem para fins acadêmicos, já planejada com muita antecedência. Compareceram à festa Celestino, Eni, Eder e Emili.

$10 \mathrm{Na}$ década de 1970, Guattari (1985[1977]: 53) fazia uma reflexão a respeito de como a televisão substituiu as tarefas de educadores convencionais - pais, mães, professoras - tornando-se uma modeladora de imaginário e inserindo personagens, ideais etc. No caso dos bebês, talvez não mais a televisão, mas caberia um estudo sobre os canais de YouTube, que, com seus potentes algoritmos, vão automaticamente apresentando aos espectadores um desenho animado após o outro, assim como videoclipes. O "Mundo Bita" foi sugerido por uma amiga, também mãe, de Renata. 
O "Mundo Bita" é composto pelo próprio Bita, a única personagem adulta cujos ícones são a cartola preta e o bigode laranja e pelas crianças Lila, Dan e Tito. Aparentemente, tudo cabe nesse "mundo", que se organiza em torno de temáticas que compõem a própria produção de vídeos, livros, brinquedos, acessórios e utensílios ${ }^{11}$ : animais, alfabeto, circo, corpo humano etc. No caso da festa de Mariana, foram elementos do cenário: miniaturas das quatro personagens; galinha, leão, vaca - todos em suas versões bebê; cata-ventos; o nome de Mariana em letras de tecido. O bolo falso, de três andares, contava com cata-ventos no andar de cima; balão, nuvem e satélite no andar do meio e um trem em sua base. Tudo isso em miniatura, "representados por meio de traços infantis ou infantilizados" (Machado 2006:394). E igualmente interessante: duas fotos de Mariana, sendo que em uma delas está vestindo uma cartola tal como a de Bita. Se, por um lado, tudo é infantilizado para caber no mundo dos bebês, de acordo com Machado (2006: 394), por outro, a associação da bebê à personagem adulta parece criar uma simetria na centralidade: Mariana em seu aniversário; Bita em seu (próprio) “mundo”.

Todavia recorrer a algo familiar - Mariana já assistia com entusiasmo aos vídeos e ouvia as músicas do "Mundo Bita" - também foi uma alternativa para prevenir um possível choro, "fiasco", nos termos da mãe, caso a bebê tivesse um susto ou reagisse negativamente à presença de tantas pessoas juntas em torno de si no aniversário. Parecia tratar-se de dois sentimentos: um dirigido para dentro da família - proteção da filha - e outro para o seu exterior, ou seja, a antecipação da vergonha diante dos convidados, caso Mariana reagisse mal à presença deles. Foi o gesto de Mariana no aniversário da prima Verônica - dedo em riste - que motivou um ritual diário que se iniciou na casa dos avós: o de cantar "Parabéns pra você".

Os ensaios da canção nas semanas que antecederam a celebração do primeiro ano, além de uma atividade evidentemente lúdica para a bebê, e também para os adultos, visava a preparar Mariana para um momento demarcado na própria festa. Esse momento conecta-se ao conceito de "priming event", que pode ser traduzido como "evento preparatório", elaborado por Corsaro e Molinari (2005), porque trata-se de uma preparação rotineira que antecipa uma transição na vida da criança. Transição, nos termos de Corsaro e Molinari, refere-se aos "processos coletivos que ocorrem dentro de contextos sociais ou institucionais" (ibid.:15, tradução minha) $)^{12}$.

A prática do "Parabéns pra você" era incentivada pela mãe, pai e avós em momentos aleatórios do dia, o que foi observado por mim em uma breve visita à família em dezembro de 2018. Em vários momentos, inclusive, fui inserida no ritual que chegou até a contar com uma vela enorme improvisada. A bebê, por sua vez, participava do ritual preponderantemente de três formas: 1) mantendo o dedo indicador em riste, gesto que ganhou uma nova interpretação: o próprio "um aninho" de Mariana, que começou pelo reconhecimento da celebração do aniversário da prima e deslocou-se para o reconhecimento de si; 2) associando a palavra ao gesto, a ponto de apontar o dedo indicador todas as vezes que os adultos comentavam acerca de seu aniversário e 3) demonstrando um enorme prazer quando segurava

11 Mais informações podem ser observadas nos sítios do "Mundo Bita" e da respectiva "lojinha": https://www.mundobita.com.br/ e https://www.lojinhadobita.com.br/

12 No original: "collective processes that occur within social or institutional contexts." 
as mãos do adulto que cantava a música e as batia com força; isso se tornou uma brincadeira repetida e realizada somente com alguns parentes próximos.

Em outra visita, com vistas a participar do aniversário, horas antes da festa, cantei "Parabéns" com Mariana. Isso geralmente ocorria quando alguém da família iniciava a canção e Mariana abarcava as mãos do adulto, com suas pequenas mãos. Nesse caso, diferente do dedo em riste, a brincadeira ganhava sentido na presença de um parceiro, que formava, com a bebê, uma dupla.

\section{Imagem 4: "Parabéns pra você".}

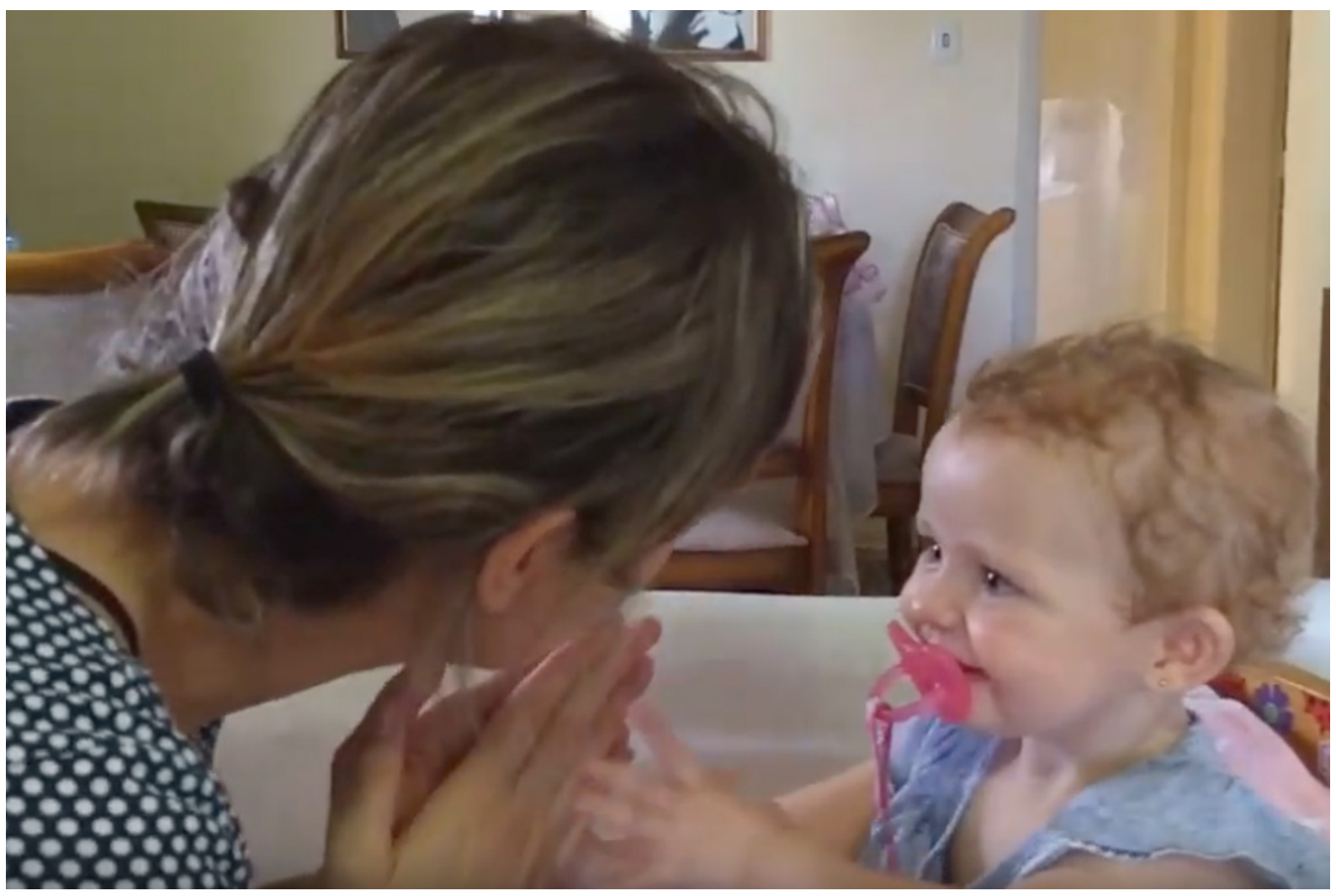

Fonte: Print de vídeo realizado por Leo no dia do aniversário em janeiro de 2019.

O "Parabéns pra você" fez parte de uma pedagogia ${ }^{13}$ produzida e compartilhada em família para assegurar a preparação de Mariana para um momento particular em sua vida, que contaria com pessoas dos mais diversos círculos de relações. Chamboredon e Prévot (1986[1973]) demonstraram que a definição social de primeira infância compreendeu a organização tanto da casa quanto da escola maternal francesa (originalmente voltada às crianças de dois a seis anos). Seguindo a tradição sociológica de Bourdieu na análise de uma questão educacional, os autores associaram ao argumento central outras variáveis, tais como classe social, instituições sociais, sobretudo a família (atividade profissional e anos

13 "Paidagōgía", em grego, significa o acompanhamento de um indivíduo. Reúne técnicas educativas associadas a qualquer processo de ensino-aprendizagem, independentemente do contexto (https://etimologia.com.br/pedagogia). 
de escolaridade da mulher) e a escola maternal. Um ponto importante é a emergência de uma pedagogia nas ações dos mais diversos membros de uma família para promover aprendizagens da criança ${ }^{14}$.

A socialização na infância e ao longo de toda a vida depende de interação e do outro para que nos tornemos humanos. Isso requer uma exposição constante aos “'filtros’ e estereótipos culturais que condicionam a percepção e o conhecimento”. (Saboya 2001:5). No decorrer da infância, a criança é inserida no mundo social como parte de um grupo, processo que não é natural, mas conectado à aprendizagem e à interação. Portanto cultura e aprendizagem são dimensões absolutamente conectadas, tal como defendiam Mead e Macgregor (1951:26, tradução minha): “culturas serão diferentes umas das outras no modo como o processo de crescimento está entrelaçado com a aprendizagem"15.

\section{"Parabéns pra você" e a transição de Mariana da família para a creche}

Tornar-se membro de uma sociedade diz respeito a "assumir o mundo no qual os outros já vivem" (Berger e Luckmann 2003:174-175), o que só é possível por meio de um processo de socialização, isto é, a "introdução do indivíduo no mundo objetivo de uma sociedade", que ocorreria em três momentos subsequentes, quais sejam: a socialização primária, a socialização secundária e a alternação ${ }^{16}$. Tratando-se de um bebê, o conceito de socialização primária explicaria um processo que ocorre na infância, com o objetivo de inserir o indivíduo na sociedade, por meio de situações face a face e de outros significativos.

Embora reconheça que a socialização assume um caráter singular na infância, Abrantes (2011) desafia a teoria de Berger e Luckmann na medida em que questiona a linearidade entre socialização primária e secundária. Nesse caso, o autor enfatiza, ao invés da construção objetiva da realidade, um processo de "como adultos e crianças vão construindo experiências, pertenças e disposições" (Abrantes 2011:125). Sua ênfase volta-se para interações, atividades e práticas sociais e menos para os contextos nos quais uma suposta linearidade operaria.

Passemos ao caso específico para posteriormente retornar à teoria. O processo de socialização de Mariana conectou-se com as experiências de transição na família e da família para a creche. Aos

$14 \mathrm{O}$ brinquedo, no contexto doméstico e da escola maternal, tornou-se essencial como parte de uma prática pedagógica. Logo, a tendência em associar prática pedagógica às ações conduzidas, geralmente por professoras, em escolas, tem a ver com uma acepção contemporânea e, na minha visão, limitada, de pedagogia. A pedagogia escolar poderia ser lida como uma "estratégia”, dentro de um discurso institucional e legitimado de como educar crianças em um contexto coletivo e compulsório; enquanto a pedagogia produzida em família, que Chamboredon e Prévot 1986[1973] associaram à mãe-pedagoga, fica na ordem da “tática”, da prática de pessoas comuns que buscam estimular o que está no centro da descoberta da primeira infância como objeto pedagógico: a criança-intelectual (Certeau 2014[2010]).

15 No original: "cultures will differ from each other in the way in which the growth process is interwoven with learning".

16 Crianças nascem em uma estrutura social objetiva, onde encontram “outros significativos” que se ocupam da sua socialização primária. Esses outros significativos são justamente os seus cuidadores imediatos, não necessariamente pai e/ou mãe. Partindo do pressuposto de que "a realidade da vida cotidiana é sempre partilhada com outros", Berger e Luckmann (2003 [1966]:46) exploram dois tipos de interação social, quais sejam, as situações face a face e as situações anônimas. A socialização primária envolve situações face a face. Já a socialização secundária, na escola, diz respeito à apreensão do conhecimento de funções específicas, que ocorre em situações anônimas. Como instituição socializadora, a escola apresenta uma passagem dos outros significativos para as generalizações, em que outros serão agregados. Os professores não mais seriam outros significativos, mas “[...] funcionários institucionais, com a atribuição formal de transmitir conhecimentos específicos” (Berger e Luckmann 2003[1966]:189). Já alternação diz respeito a um possível processo de ressocialização (alcoolismo, por exemplo, tal como documentado por Campos e Ferreira 2007), mais próximo à socialização primária, em um estágio mais adiantado de vida. 
14 meses, Mariana já tinha passado por algumas transições, começando pelo próprio nascimento. A segunda transição foi de sua permanência quase que diária, no turno da tarde e na companhia da mãe, na casa dos avós maternos nos primeiros meses. Passados seis meses, Mariana começou a ser cuidada pelos avós sem a presença da mãe no turno da tarde, o que correspondia a uma experiência diária em dois contextos domésticos; essa poderia ser considerada uma terceira transição.

A segunda e a terceira transições ocorreram de forma bastante planejada. A mãe antecipou que em seis meses voltaria parcialmente ao trabalho e decidiu acompanhar os cuidados dos avós em relação à Mariana no próprio contexto em que ela depois permaneceria. Era assumida naquele momento o que Motta-Maués (2004: 439) chamou de "criação compartilhada", na medida em que a bebê continuava morando e sendo criada pelos pais, mas, por um período do dia, sendo cuidada pelos avós.

Já os avós prepararam-se para a estadia da neta em sua casa, a começar pela compra de móveis e utensílios domésticos que tentavam reproduzir e duplicar ambientes que a bebê tinha na própria casa. Assim, na casa dos avós, Mariana tinha o próprio quarto com berço, carrinho, brinquedos, balanço, chupetas, roupas, alimentos e itens de higiene. Além disso, organizaram uma rotina, que ora contemplava as necessidades da criança - um bom exemplo é a pontualidade das mamadeiras e da troca de fraldas-, ora dos avós - quando faziam a bebê dormir, coincidentemente, nos próprios horários habituais de $\operatorname{sesta}^{17}$.

A notícia de que Mariana iria para a creche foi dada em fevereiro de 2019 (quando a bebê completou 13 meses). A mãe contou à avó e à tia maternas que havia visitado duas instituições com a bebê e que fez a escolha diante da observação atenta de suas ações naqueles ambientes, sua curiosidade e maior interesse de exploração. A visita, de acordo com a teoria de Corsaro e Molinari (2005), seria outro "evento preparatório", na medida em que antecipou e preparou a futura inserção em uma das creches.

Ir para a creche ${ }^{18}$ faz parte da experiência de milhares de bebês e crianças pequenas de zero a três anos. No Brasil, 35,6\% foram atendidas em creches públicas e privadas em 2019, o que equivale a 3,6 milhões de crianças (IBGE 2019) ${ }^{19}$. Noções a respeito da creche estiveram associadas ao atendimento de necessidades biológicas das crianças pequenas, isto é, alimentação, sono e higiene, o que produziu um estigma como "mal necessário" (Vieira 1988), sobretudo para as famílias pobres em que as mulheres precisavam trabalhar - "um direito associado ao trabalho das mães e não um direito à educação dos filhos" (Rosemberg 2015: 177).

As necessidades decorrentes do trabalho das mães, as expectativas sobre o desenvolvimento e bom atendimento da criança na creche circulam tanto em classes populares quanto em classes médias. Todavia não esqueçamos que as mães de classe média têm os melhores empregos, níveis superiores de formação e renda e residem em áreas urbanas (Rosemberg 2015). A creche, entre a classe média, parece

17 A avó manteve de abril de 2018 a dezembro de 2019, período em que Mariana ficou sob os seus cuidados, um diário onde registrou informações sobre a neta, incluindo a dieta e a ocorrência de troca de fraldas. Decorre de sua análise desse material o orgulho por a neta jamais ter tido qualquer assadura.

18 Rosemberg (2015) argumenta que parte da sociedade latino-americana não considera a creche como uma instituição educacional. Inclusive, a autora (2015: 170) sugere a leitura do trabalho de Alma Gottlieb, na medida em que vê conexões entre as razões para essa dissociação e os argumentos da antropóloga sobre a ausência de bebês em pesquisas: "proximidade com o corpo? Formas de comunicação alheias às práticas do sistema educacional construído na modernidade? Fobia de adultos ocidentais frente aos eflúvios dos bebês?”.

19 Destas, 65,4\% foram atendidas em creches públicas, enquanto 34,6\% em creches privadas (INEP 2019). 
atender a uma noção de direitos da criança e a opção da família. O discurso de Renata pela escolha daquele momento para a entrada de Mariana na creche parecia orientado por uma noção de desenvolvimento produzida pelo campo da Psicologia e já bem disseminada no senso comum ${ }^{20}$. Voltava-se para uma expectativa de qualidade do atendimento que promovesse o desenvolvimento integral de Mariana.

A notícia, todavia, criou as mais diversas expectativas. Se, por um lado, o que se sobressaía no discurso da avó materna era a preocupação com a sua perda de exclusividade no cuidado à criança, por outro, ela reconhecia, ainda que com ressalvas, que era o momento de a mãe voltar integralmente ao trabalho. Mariana então passou pela quarta transição, qual seja, permanecer na creche no período matutino $^{21}$, enquanto à tarde era mantida sob os cuidados dos avós maternos ${ }^{22}$. Se nos três primeiros dias na creche, ainda contando com a presença da mãe nas dependências, a bebê demonstrou prazer na exploração de brinquedos e do próprio espaço, chegando a não olhar para trás para se despedir, do quarto ao décimo dia a sua adaptação não foi entendida como a mais tranquila. Passou a chorar intensamente nos momentos de chegada, sobretudo, quando os pais se despediam dela. Enquanto se encontrava na casa dos avós, à tarde, houve alguns episódios de choro - "quando víamos, estava com os olhinhos cheios d'água", dizia a avó - que foram compreendidos como uma tentativa de comunicar a frustração pela separação da mãe e do pai no momento de chegada à creche.

Mariana demonstrava um sentimento bastante inédito em sua vida e na dos adultos envolvidos, que foi interpretado como um compilado de frustração, desprezo e tristeza. Terzi e Mantovani (1998) argumentam que certo nível de frustração é necessário para crescer, mas, naquele contexto familiar e sobretudo na visão da avó, um possível desconforto não combinava com as expectativas em relação à educação e ao cuidado de sua primeira e única neta.

Mãe, pai e avós passam então a interpretar as ações da criança. Mais precisamente, foram as mulheres - bisavó, avó, mãe e irmã da mãe - que descreveram, interpretaram e traduziram essas mudanças na vida da bebê, cuja construção de gênero também vai sugerir uma proximidade maior a essa linha materna e feminina da família. Independentemente de estar a dois mil quilômetros de distância, eu era e sou acionada pela rede de sociabilidade das mulheres. Dentre as demandas, era consultada acerca de questões não resolvidas nas situações face a face (Goffman 1985), o que, em muitos momentos, envolveu conflitos; era a destinatária de vídeos, fotografias, mensagens sobre a criança; era autorizada ou não a palpitar a respeito de questões que envolviam a educação de Mariana.

20 O fato de pais e mães buscarem no modus operandi da creche o estímulo a um aspecto da realidade psicológica - o desenvolvimento sugere mecanismos de legitimação institucional. Mais do que isso, essa legitimação encontra lugar no universo simbólico, que é a "matriz de todos os significados socialmente objetivados e subjetivamente reais.” (Berger e Luckmann 2003[1966]: 132). O universo simbólico também ordena e legitima os papéis cotidianos, logo, parece que o desenvolvimento vem ao encontro de uma tipificação construída na realidade social, no senso comum, sobre ser criança e torna possível a existência das instituições, nesse caso, a creche.

21 Verônica passou a frequentar a creche com sete meses, após a licença maternidade de Élen. As irmãs Marlene e Eni conversavam e trocavam mensagens sobre o tema, inclusive, a primeira preocupou-se com uma necessária viagem da segunda à casa da filha para ajudar com os cuidados à neta, que, nos primeiros meses na creche, contraiu uma otite persistente.

22 A partir de janeiro de 2020, Mariana passou a frequentar a creche das 11 h às $18 \mathrm{~h}$. Essa quinta transição não é aqui tratada. Logo, a partir desse momento, permanecia em casa com a mãe no período da manhã e após a frequência à creche. Com essa mudança na rotina, visitava os avós eventualmente. No dia do segundo aniversário, ficou na creche somente até às $14 \mathrm{~h}$, um encurtamento da jornada devido à preparação para a festa, que ocorreu em outro salão, com um número considerado de convivas. Nesse dia, a professora e as crianças cantaram "Parabéns pra você" e Mariana ganhou um pacote com duas frutas de presente e um cartão. 
Diante da dificuldade em ficar na creche, demonstrada pelo choro copioso, a avó chegou a duvidar da vantagem dessa experiência. Lançou mão de ligações telefônicas mais frequentes a mim (que muito se diferenciavam da frequência de antes do nascimento da neta), quando tentava dar um sentido ao choro, que imaginava que era ouvido por quem quer que passasse pela rua da creche, mesmo sem ter jamais acompanhado esse momento. Crítica às regras da creche, que chegou a comparar a uma "ditadura”, a avó pensou que a professora deveria receber Mariana e imediatamente organizar os demais bebês para, em torno dela, juntos, cantarem "Parabéns pra você". A avó tinha certeza de que se essa estratégia fosse seguida, ao menos nos primeiros dias, Mariana teria se sentido bem melhor. O choro não poderia ter sido lido pela avó de pior forma, que, por sua vez, foi professora de crianças pequenas por 25 anos. Nesse caso, a identidade de professora, que já havia lidado com inúmeras situações de choro, informava a de avó que algo deveria ser feito.

Também a avó alegava que a creche teria de ser ainda melhor que a sua própria casa, onde a criança é, sem dúvida, mais paparicada do que educada (vide Ariès 1981[1973]). Para compensar o suposto sofrimento da neta na creche, avó e avô nunca ofereceram tanto colo, chupeta (já que a avó pensava que não era permitida na creche, o que não ocorria de fato), biscoito de amido de milho (proibido pela mãe) e afago tão logo a bebê chegava.

Mariana encontrava na casa dos avós tudo e mais um pouco daquilo que tinha na própria casa. O interessante é que, ainda que em um tom pretensamente discreto, para os padróes de uma avó de primeira viagem e bastante envolvida, também queria interferir na transição para a creche. A avó tinha a expectativa de que o ritual transitasse entre, no mínimo, três contextos: o familiar, o da festa de aniversário e o da creche.

\section{Família e creche: contextos de aprendizagem e de negociação}

Ingold reconhece a ação das crianças ao afirmar que elas "não aprendem a entrar no mundo social, mas simplesmente entram nele" (2007:113, tradução minha) ${ }^{23}$. Na visão do autor, os adultos passam por uma experiência transformadora ao criarem crianças, o que o leva a uma noção de socialização como um processo que não se encerra na infância, mas estende-se por toda a vida - o que também é defendido por Abrantes (2011). Ingold (2007), todavia, vê problemas com o uso do termo socialização, pois, na sua visão, não conseguiria descrever o que se passa enquanto a criança está aprendendo. Por esse motivo, ele sugere outro termo, enskillment, melhor traduzido como "habilitação", que compreenderia aprendizagem com parceiros mais experientes na interação.

Mariana é filha única por parte de mãe e quatorze anos mais nova que o meio-irmão, Eric, por parte de pai, que não vive com ela. Essa condição de exclusividade (que também experimenta na casa dos avós), principalmente observada na linha materna, também gerou preocupação, sobretudo na mãe. Logo, a busca pela creche, mais do que o retorno definitivo da licença-maternidade (a mãe trabalhou somente meio período dos seis aos 14 meses de Mariana), foi justificada pela necessidade de desenvolvimento, como já tratado anteriormente, mas também de socialização da criança. Socialização foi defini-

23 No original: "Children learn not to gain entry to the social world but to make their way within it". 
da pela mãe como a aprendizagem de compartilhar, dividir com o outro, nesse caso, outras crianças. De fato, a mãe observava que, até os 14 meses, Mariana pouco interagiu com pares, dentro de uma rotina diária em que os adultos tinham (e ainda têm) dificuldades em frustrar seus desejos.

Com a transição para a creche, a bebê deixou de contar somente com os adultos de referência de casa e passou a interagir com outras pessoas, adultos e crianças, de forma rotineira. Mais do que isso, a bebê e a família passaram a experimentar um conjunto de emoções acionado a partir dessas novas relações.

A aceitação de Mariana em permanecer na creche e não mais chorar compulsivamente, após o décimo dia, deu à avó certa tranquilidade. Igualmente, deu-lhe mais tempo para exercitar comparações entre as ações da criança em sua casa antes e depois da inserção à creche. Toda e qualquer atitude entendida como inadequada, na sua visão, foi aprendida com os demais bebês, na creche. Destacou, inúmeras vezes, o fato de Mariana bater a cabeça na parede ou em algum móvel como uma forma de protesto, quando contrariada. Também, a bebê desenvolveu uma tática de armazenar água na boca e posteriormente cuspi-la, especialmente, no chão já limpo. Ainda, no inverno, passou a deitar-se no chão diante de uma frustração. Tudo de negativo só poderia ter sido aprendido na creche e com uma rapidez surpreendente.

Mas também são constantes os relatos da avó que reconhecem outras aprendizagens de Mariana. O primeiro deles referiu-se à dieta - uma preocupação também registrada por Chamboredon e Prévot (1986[1973]) entre as mães francesas. Até os cinco meses, Mariana alimentou-se de leite materno, seguido de mamadeira, sopas e purês. A partir dos cinco meses, já comia pequenos pedaços de alimentos e uma boa variedade de frutas. $\mathrm{Na}$ creche, Mariana passou a beber água e chás diversos não mais em mamadeira, mas em copo. Foi também exposta a um cardápio mais diversificado daquele com que estava habituada, que incluía arroz com ervas, cookie integral, frutas ácidas, vegetais diversos, grãos e carnes. Os relatórios diários descritos na agenda pela professora eram lidos pelo avô assim que Mariana chegava à sua casa. Era a sua primeira ação depois de abraçar e beijar a neta. E esse era um momento esperado, para checar o que e quanto havia comido; quais porções havia repetido; se havia dormido e por quanto tempo; e quantas vezes havia ocorrido trocas de fralda. A avó reconheceu que na creche a neta se alimentava melhor do que em sua própria casa e chegou a pedir à mãe que obtivesse receitas de certos alimentos com as cozinheiras.

É por meio de uma nova relação, construída em outro "contexto negociado" (Ingold 2007), nesse caso, na creche, por que um novo sistema de cuidado passa a ser aprendido e oferecido à criança no contexto doméstico. As rotinas alimentares da casa dos pais e da dos avós passam a incorporar gostos que não se sabia que a bebê tinha, porque certos alimentos ainda não haviam sido apresentados a ela. Aprendeu, portanto, na creche.

Também relacionada à alimentação, mas não restrita a ela, ocorreu uma situação na creche quando Mariana já tinha 17 meses. O episódio começou na creche, circulou entre as mulheres e foi resolvido em casa, pelo pai. A mãe foi abordada pela professora quando foi buscar Mariana. Nessa conversa, a professora então relatou que diante da comida, Mariana apelava, geralmente, para duas alternativas: ou comia com as mãos ou demandava dela ou de sua auxiliar que a alimentassem. Além disso, a professora 
sugeriu que Mariana estaria em defasagem em relação às demais crianças da turma, já que estas comeriam com colher e autonomamente.

O episódio gerou um desabafo da mãe, centrado em algumas questões, dentre elas: uma possível culpa por talvez não estar estimulando Mariana suficientemente; a dúvida de talvez estar impedindo o seu desenvolvimento, embora ciente de que sempre motivou a autonomia de Mariana; chegou a pensar que talvez estivesse a tratando como "uma bebezinho", nos seus termos; e o constrangimento pela exposição dela, enquanto mãe e da própria criança. Aqui, parece ocorrer novamente um misto de sentimentos, tanto internos à família quanto em relação à creche, sendo a vergonha um deles.

Para tornar a questão mais nevrálgica, há, ainda que muito disfarçada, uma comparação intergeracional em relação às habilidades de Mariana na família. Ou seja, a avó compara Mariana com as suas duas filhas quando tinham a mesma idade, no que se refere às práticas de alimentação, controle de esfíncteres, aquisição da fala, desenvolvimento motor e até mesmo personalidade. Como avó, parece que ela se atualiza na condição de mãe para observar que certos processos das filhas ocorreram antes do que os da neta: falaram, caminharam, deixaram as fraldas bem mais cedo ${ }^{24}$.

O alívio, todavia, a respeito do uso dos talheres, nesse caso, da colher, ocorreu três dias depois do informe da professora, quando, em um domingo pela manhã, o pai ofereceu à Mariana um prato com banana picada.

Imagem 5A, 5B, 5C: Mariana em três momentos da colação matinal.

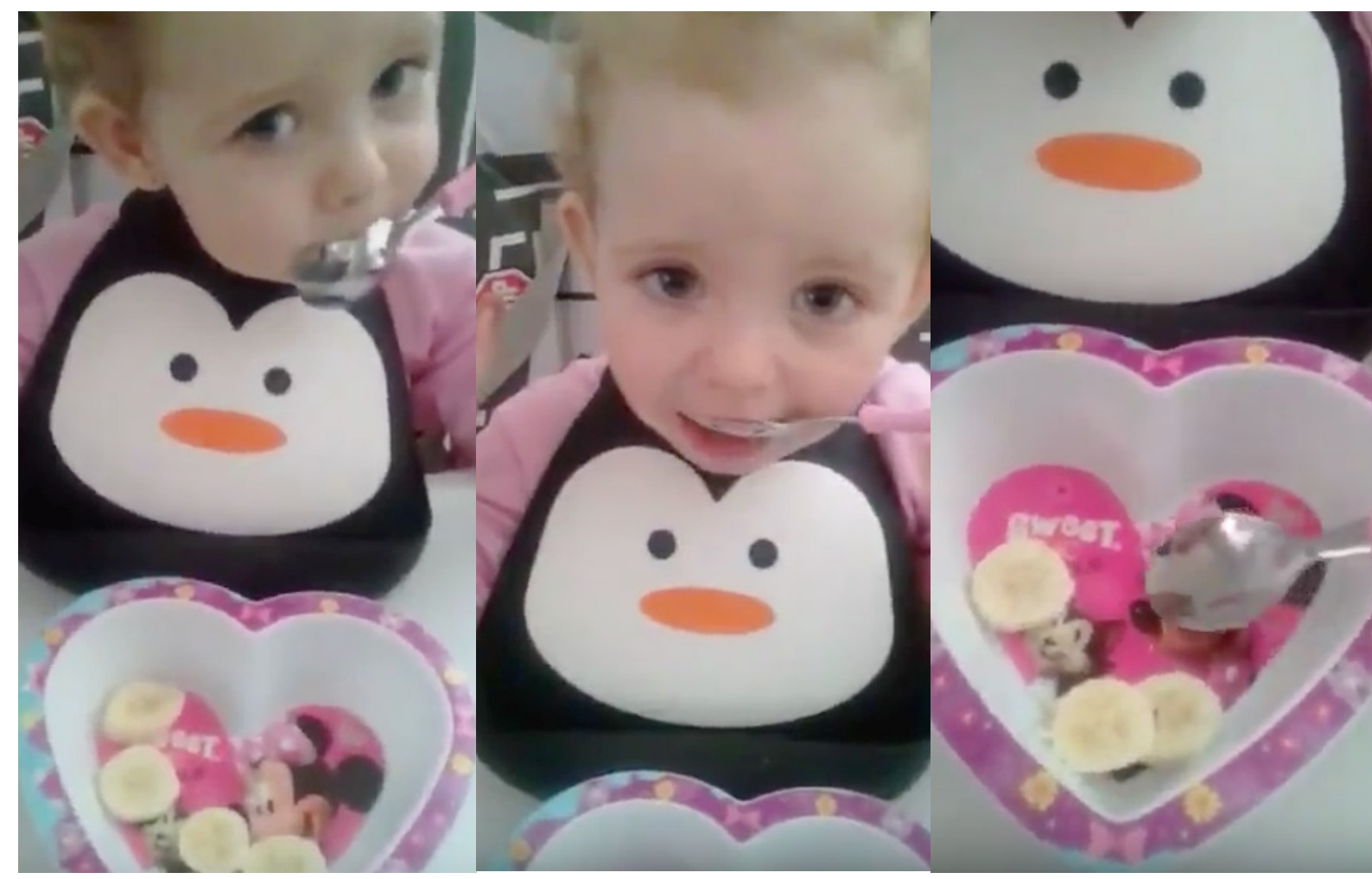

0:01

$0: 10$

$0: 18$

Fonte: Prints de vídeo realizado por Rodrigo.

24 Tal como argumentado por Zhu (2010), ainda que para o contexto contemporâneo da China, as interpretações da avó e da mãe de Mariana reforçam suas identidades separadas ao mesmo tempo em que produzem "práticas maternas híbridas" em relação à bebê. 
Mariana não hesitou em tomar a colher e servir-se da fruta. Até um vídeo, de 21 segundos, foi registrado pelo pai e imediatamente enviado a mim pela mãe. Era a prova de que ela era competente ao manusear o talher, ao contrário da sugestão da professora. Diferentes adultos colaboram entre si, direta e indiretamente, para aprendizagens mútuas, ainda que nem sempre livres de conflito. Se as professoras da creche precisam aprender sobre as crianças e sua relação em família, também é fato que pais, mães e inclusive os avós aprendem a respeito dessa nova relação - seja com professoras, seja com outros bebês.

Crianças são agentes da socialização de pais, mães, avós, tios, tanto quanto os adultos são agentes na socialização delas, acionando um "processo de mão dupla" (Ingold 2007). E essa noção de Ingold encontra conexão em James (2013:72, tradução minha), que, igualmente negando uma noção clássica de socialização (durkheimiana) - segundo a qual a família operaria verticalmente - argumenta que "são as crianças que, ao viver com sua família, aprendem, refletem e até ajudam a moldar seus valores, atitudes e papéis específicos"25.

Esses processos mútuos de aprendizagem e "habilitação" podem ser associados à construção de identidades que inexistiam antes da concepção de Mariana, já que sua existência é significada mesmo antes do nascimento. A noção de pessoa já existia quando, diante das ecografias tridimensionais se nomeava, não a bebê, mas Mariana ou "Mari” e já se buscavam semelhanças com os familiares. Esse é um aspecto da socialização de mão dupla: uma criança é inserida e apresentada ao mundo, ao mesmo tempo em que pai, mãe, bisavós, avós, tios, primos também o são, a partir dessas novas identidades.

\section{Conclusão}

Bebês são centrais em uma família. No caso particular de Mariana - e de Verônica - ela ocupa todos os tempos e espaços quando presente e não presente. Portanto, foi considerada agente central de emoções, tensões e produções identitárias dos demais membros da família entre si e na relação com a creche. Trata-se de uma experiência que não tem pretensão de ser generalizada, porém, em certa medida, pode encontrar similaridades e contrastes com a de milhares de bebês brasileiros que ingressam na creche a partir do primeiro ano de vida ou mesmo antes.

Norbert Elias (2012: 469) sugeriu como parte de um projeto moderno de ajuda às crianças um "incontornável processo civilizador individual, pelo qual cada um transforma-se em adulto, sem que suas possibilidades de gozo e alegria se deteriorem". Socializar-se ou civilizar-se seriam, nessa perspectiva, sinônimos. É durante a infância que a criança é exposta a modos de se comportar, comer, andar e vai ganhando um contorno a partir da aprendizagem desses códigos. Os adultos conhecem os códigos, porém necessitam reaprendê-los e/ou reajustá-los dependendo da situação. Por exemplo, na relação com sua filha, Renata experimentou um conjunto de sentimentos diante da possível reação negativa de Mariana perante tantos/as convidados/as na festa de primeiro ano e do comunicado da professora sobre os seus modos à mesa.

25 No original: "it is children who, by living with their family, come to learn about, reflect on and even help shape its particular values, attitudes and roles". 
O trabalho buscou descrever transições que acompanharam o processo de socialização de uma bebê e sua família. A noção de socialização primária, embora importante conceito sociológico, requer uma necessária atualização. Teorias sensíveis a processos tão complexos pelos quais passam crianças e adultos têm questionado supostas continuidades e linearidades. Se Abrantes (2011) chama atenção para a globalização como uma questão fundamental, que desafia as fronteiras da socialização tradicional (primária, associada à família, e secundária, associada à escola), a descrição deste trabalho mostra duas necessidades contemporâneas: 1) de retomada das atividades profissionais das mães; e 2) de um processo de socialização fora do contexto familiar. Assim, os "outros significativos" não se resumiriam mais aos parentes. Até a suspensão de atividades em função da pandemia, a creche educou e cuidou de Mariana por um tempo comparável ao despendido na casa dos avós e menos que aquele vivido em sua própria casa fora dos momentos de sono. Mais do que isso, os eventos, episódios e rituais também precisam ser considerados e observados como parte do processo de socialização das crianças, para além das instituições família ou creche.

As alternativas teóricas acerca da socialização apresentadas por Ingold e James parecem responder mais às realidades contemporâneas, na medida em que reconhecem um processo de mão dupla e de aprendizagem tanto de crianças como de adultos, que estão em permanente relação. A reiteração do "Parabéns pra você" como um "evento preparatório", mas, posteriormente, aventado como um possível ritual para a permanência mais tranquila de Mariana na creche, deu pistas para a reflexão acerca de consideráveis transições na vida de bebês, mas também de adultos.

Fernanda Müller é Doutora em Educação pela Universidade Federal do Rio Grande do Sul (UFRGS) e Professora Associada III da Universidade de Brasilia (UnB). A pesquisa que dá origem ao artigo contou com o auxílio financeiro da Fundação de Apoio à Pesquisa do Distrito Federal (FAP/DF) e da Universidade de Brasilia.

\section{REFERÊNCIAS BIBLIOGRÁFICAS}

Abrantes, Pedro. 2011. "Para uma teoria da socialização". Sociologia - Revista da Faculdade de Letras da Universidade do Porto, XXI: 121-139. Disponível em http://ojs.letras.up.pt/index.php/Sociologia/article/view/2229/2064. Acesso em 10 Mar. 2019.

Amorim, Katia de Souza, Telma Vitoria e Maria C. Rossetti-Ferreira. 2000. "Rede de significações: perspectiva para análise da inserção de bebês na creche”. Cad. Pesqui. 109: 115-144. http://dx.doi. org/10.1590/S0100-15742000000100006.

Ariès, Philippe. 1981[1973]. História social da infância e da família. Rio de Janeiro: LCT. 
Augé, M. 1975. “Introdução ao vocabulário do parentesco". Pp. 11-72 in Os Domínios do Parentesco. Lisboa: Edições 70.

Berger, Peter e Thomas Luckmann. 2003[1966]. A Construção Social da Realidade. Rio de Janeiro: Vozes.

Campos, Geraldo M. de e Ricardo F. Ferreira. 2007. “A importância da legitimação social na (re) construção da identidade de um alcoolista”. Estud Psicol.24(2): 215-25. doi: https://doi. org/10.1590/S0103-166X2007000200008

Cardoso de Oliveira, Roberto. 1996. "O Trabalho do Antropólogo: Olhar, Ouvir, Escrever”. Revista de Antropologia 39(1): 13-37. Disponível em https://www.revistas.usp.br/ra/article/ view/111579/109656. Acesso em 13 Jun. 2017.

Certeau, Michel de. 2014[1990]. A invenção do cotidiano: artes de fazer. Petrópolis: Vozes.

Chamboredon, Jean-Claude e Jean Prévot. 1986[1973]. “O 'ofício de criança’: definição social da primeira infância e funções diferenciais da escola maternal”. Cadernos de Pesquisa 59: 32-56. Disponível em http://publicacoes.fcc.org.br/ojs/index.php/cp/article/view/1305/1308. Acesso em 13 Jun. 2019.

Corsaro, William e Luisa Molinari. 2005. I Compagni: understanding children's transition from preschool to elementary school. New York: Teachers College Press.

Coutinho, Ângela Maria S. 2010. As ações sociais dos bebês: um estudo etnográfico no contexto da creche. Tese de Doutorado. Instituto de Educação, Universidade do Minho.

Duarte, Luiz Fernando Dias e Edlaine de Campos Gomes. 2008. Trêsfamílias: identidades e trajetórias transgeracionais nas classes populares Rio de Janeiro: Editora FGV.

Elias, Norbert. 2012. “A civilização dos pais”. Sociedade \& Estado 27(3): 469- 493. doi: https://doi. org/10.1590/S0102-69922012000300003

Geertz, Clifford. 1989. A Interpretação das Culturas. Rio de Janeiro: LTC.

Goffman, Erving. 1985. A representação do eu na vida cotidiana. Petrópolis: Vozes.

Goodwin, Charles. 2007. "Environmentally Coupled Gestures". Pp. 195-212 in Gesture and the Dynamic Dimension of Language, ed. S. D. Duncan; J. Cassell \& E. T. Levy. Amsterdam: John Benjamins.

Gottlieb, Alma. 1998. "Do Infants Have Religion? The Spiritual Lives of Beng Babies." American Anthropologist 100(1): 122-35. doi: https://doi.org/10.1525/aa.1998.100.1.122 
Gottlieb, Alma. 2000. "Where Have All The Babies Gone?: Toward an Anthropology of Infants (and Their Caretakers)”. Anthropological Quarterly 73(3):121-132. doi: https://doi.org/10.1353/ anq.2000.0006

Gottlieb, Alma. 2004. The Afterlife is where we come from: the culture of infancy in West Africa. Chicago: University of Chicago Press.

Guattari, Félix. 1985 [1977]. Revolução Molecular: pulsações políticas do desejo. São Paulo: Editora Brasiliense.

Hardman, Charlotte. 1973. "Can there be an Anthropology of Children?". Journal of the Anthropological Society of Oxford IV(2): 85-99. Disponível em: https://www.anthro.ox.ac.uk/sites/default/files/ anthro/documents/media/jaso4_2_1973_85_99.pdf. Acesso em 09 Fev. 2017.

Hirschfeld, Lawrence A. 2002. "Why Don't Anthropologists Like Children?". American Anthropologist 104(2): 611-627. Doi: https://doi.org/10.1525/aa.2002.104.2.611.

IBGE. 2019. Pesquisa Nacional por Amostra de Domicilios Contínua: Educação 2019. IBGE: Rio de Janeiro. Disponível em: https://biblioteca.ibge.gov.br/visualizacao/livros/liv101736_informativo. pdf. Acesso em 10 Mai. 2020.

INEP. Sinopses Estatísticas da Educação Básica - 2019. 2019. Inep: Brasília. Disponível em: http:// download.inep.gov.br/informacoes_estatisticas/sinopses_estatisticas/sinopses_educacao_basica/ sinopse_estatistica_educacao_basica_2019.zip. Acesso em 09 Mai. 2020.

Ingold, Tim. 2007. “The social child”. Pp. 112-118 in Human development in the twenty-first century: a dynamic systems approach to the life sciences, ed. A. Fogel, B. King \& S. Shanker. Cambridge: Cambridge University Press.

James, Allison. 2013. Socialising children. London: Palgrave Macmillan.

Machado, Igor J. de Renó. 2006. “Sobre bebês e totemismo". Mana 12(2): 389-418. doi: https://doi. org/10.1590/S0104-93132006000200006.

Machado, Igor J. de Renó. 2013. “O inverso do embrião: reflexões sobre a substancialidade da pessoa em bebês prematuros”. Mana 19(1): 99-122. doi: https://doi.org/10.1590/S010015742008000100008.

Mantovani, Susanna e Nice Terzi. 1998. “A Inserção”. Pp. 173-184 in Manual de Educação Infantil: de 0 a 3 anos uma abordagem reflexiva, ed. A. Bondioli e S. Mantovani. Porto Alegre: Artmed.

Mauss, Marcel. 1973 [1938]. Sociologia e Antropologia. São Paulo: EPU/Edusp. 
Mauss, Marcel. 2010 [1937]. “Três observações sobre a sociologia da infância”. Pro-Posições 21(3): 237-244. doi: https://doi.org/10.1590/S0103-73072010000300014

Mead, Margaret e Frances C. Macgregor. 1951. Growth and culture: a photographic study of Balinese childhood. New York: G. P. Putnam's Sons New York.

Motta-Maués, Maria Angelica. 2004. "Na 'casa da mãe'/na 'casa do pai': Anotações (de uma antropóloga e avó) em torno da 'circulação' de crianças". Revista de Antropologia 47(2): 427-452. doi: https:// doi.org/10.1590/S0034-77012004000200003

Pires, Flávia F. e Marina R. Saraiva. 2019. "Enquanto houver bebês, há esperança”. Áltera, 1(8): 09-13. doi: https://doi.org/10.22478/ufpb.2447-9837.2019v1n8.46821

Rocha, Eloisa A. C. e Fernanda Gonçalves. 2015. “A produção científica sobre a educação de bebês e crianças pequenas no contexto coletivo da creche". Poiésis 9(15): 44-62. doi: http://dx.doi. org/10.19177/prppge.v9e15201544-62.

Rosemberg, Fulvia. 2015. “A cidadania dos bebês e os direitos de pais e mães trabalhadoras”. Pp. 162-183 in Creche e feminismo: desafios atuais para uma educação descolonizadora, ed. D. Finco, M. A. Gobbi e A. L. G. de Faria. Campinas: Edições Leitura Crítica; Associação de Leitura do Brasil ALB; São Paulo: Fundação Carlos Chagas.

Saboya, Maria Clara L. 2001. “O Enigma de Kaspar Hauser (1812?-1833): uma abordagem psicossocial”. Psicologia USP 12(2): 105-117. doi: https://doi.org/10.1590/S0103-65642001000200007.

Salutto, Nazareth e Anelise M. do Nascimento. 2019. "Onde estão os bebês? reflexões para sua construção conceitual a partir de um debate interdisciplinar”. Áltera 1(8): 14-37. doi: https://doi. org/10.22478/ufpb.2447-9837.2019v1n8.40759

Silva, Angélica A. F. e Fernanda Müller. 2015. "Análise de conteúdo da produção acadêmica em Educação: tendências nos estudos da primeira infância na creche”. Teias 16: 174-189. Disponível em: https://www.e-publicacoes.uerj.br/index.php/revistateias/article/view/24557/17537. Acesso em 07 Mar. 2020.

Silva, Elenice de B. T. e Vanessa F. A. Neves. 2020. "Os estudos sobre a educação de bebês no Brasil”. Educação Unisinos online 24: 01-19. Disponível em: http://revistas.unisinos.br/index.php/educacao/article/view/edu.2020.241.07/6074765 Acesso em 09 Nov. 2020.

Sirota, Régine. 2014. “Anniversaires: le rituel du gâteau”. L'école des parents (611): 28-29. doi: https:// doi.org/10.3917/epar.611.0028

Toren, Christina. 2004. “Do Babies Have Culture?”. Anthropological Quarterly 77(1): 167-179. doi: https://doi.org/10.1353/anq.2004.0014 
Vasconcelos, Cleido R. F. et al. 2003. "A incompletude como virtude: interação de bebês na creche”. Psicol. Reflex. Crit. 16(2): 293-301. doi: https://doi.org/10.1590/S0102-79722003000200009

Vieira, Lívia. M. F. 1988. “Mal Necessário: creches no Departamento Nacional da Criança”. Cadernos de Pesquisa 67: 03-16. Disponível em: http://publicacoes.fcc.org.br/ojs/index.php/cp/article/ view/1215/1220. Acesso em 10 Set. 2020.

Zhu, Jianfeng. 2010. "Mothering Expectant Mothers: Consumption, Production, and Two Motherhoods in Contemporary China". Ethos 38: 406-412. doi: https://doi.org/10.1111/j. 1548-1352.2010.01158.x 


\title{
“PARABÉNS PRA VOCÊ”: REFLEXÕES NA QUARENTENA SOBRE A TRANSIÇÃO DE UMA BEBÊ PARA A CRECHE
}

Resumo: Este artigo pretende oferecer algumas reflexões à Antropologia, ao explorar várias transições de uma bebê e de suas cuidadoras ao longo de seus primeiros dois anos de vida, como parte de um processo de socialização. Há uma forte dimensão de vínculo, uma vez que a autora é tia e madrinha da bebê. A reflexão é baseada em dados discursivos e audiovisuais produzidos pela avó e pela mãe, associados à observação participante. São acionadas teorias contemporâneas acerca da socialização que superam noções clássicas baseadas em continuidade/linearidade. A transição de família para a creche é considerada para demonstrar que a socialização envolve um processo de mão dupla.

Palavras-chave: Bebês; creche; família; socialização; transição.

\section{“HAPPY BIRTHDAY TO YOU”: QUARANTINE THOUGHTS ON A BABY'S TRANSI- TION TO THE DAY CARE CENTER}

\begin{abstract}
This article intends to offer a contribution to Anthropology, since explores several transitions of a baby girl and her caregivers during her first two years of life, as part of a socialization process. There is a strong dimension of bonding, since the author is the baby's aunt and godmother. The analysis is based on discursive and audiovisual data produced by the grandmother and mother, associated with participant observation. Contemporary theories on socialisation are considered to question classical notions based on continuity/linearity. The transition from family to day care center is considered to demonstrate the socialization involves a two-way process.
\end{abstract}

Key-words: Babies; day care center; family; socialization; transition.

RECEBIDO: $31 / 05 / 2020$

APROVADO: $21 / 12 / 2020$ 